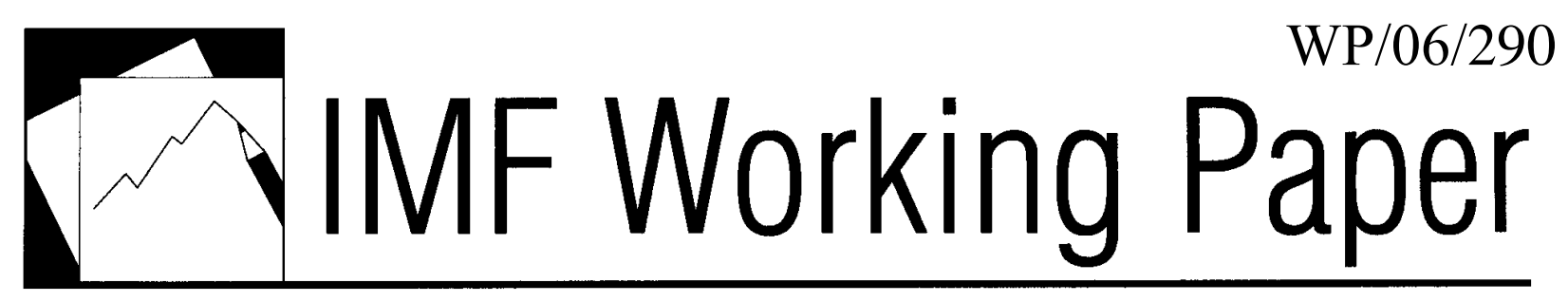

\title{
A Gravity Model of Workers' Remittances
}

Erik Lueth and Marta Ruiz-Arranz 



\title{
IMF Working Paper
}

Asia and Pacific Department

\section{A Gravity Model of Workers' Remittances}

Prepared by Erik Lueth and Marta Ruiz-Arranz

Authorized for distribution by Charles F. Kramer

December 2006

\begin{abstract}
This Working Paper should not be reported as representing the views of the IMF. The views expressed in this Working Paper are those of the author(s) and do not necessarily represent those of the IMF or IMF policy. Working Papers describe research in progress by the author(s) and are published to elicit comments and to further debate.

This paper creates the first dataset of bilateral remittance flows for a limited set of developing countries and estimates a gravity model for workers' remittances. We find that most of the variation in bilateral remittance flows can be explained by a few gravity variables. The evidence on the motives to remit is mixed, but altruism may be less of a factor than commonly believed. Most strikingly, remittances do not seem to increase in the wake of a natural disaster and appear aligned with the business cycle in the home country, suggesting that remittances may not play a major role in limiting vulnerability to shocks. To encourage remittances and maximize their economic impact, policies should be directed at reducing transaction costs, promoting financial sector development, and improving the business climate.
\end{abstract}

JEL Classification Numbers: F24, J61, O11, O24

Keywords: Bilateral remittance flows; gravity model

Author's E-Mail Address: elueth@imf.org; mruizarranz@imf.org 


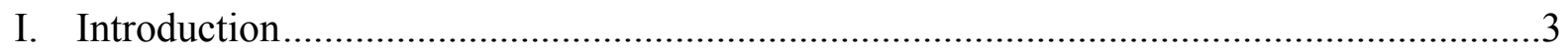

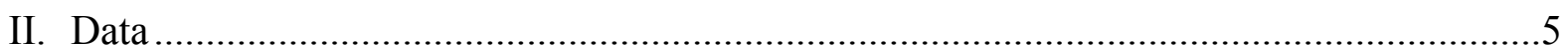

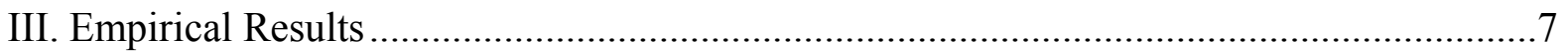

IV. Conclusions and Policy Implications ................................................................... 12

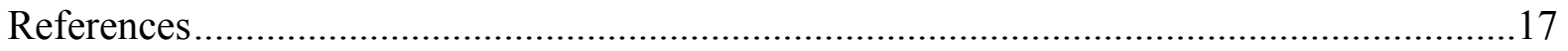

Tables

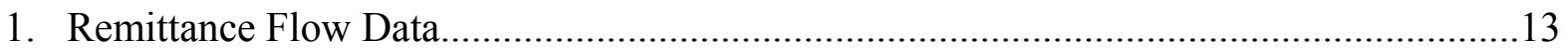

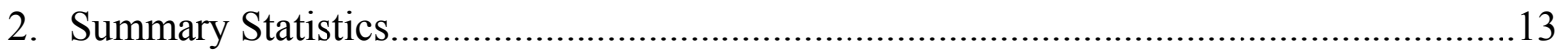

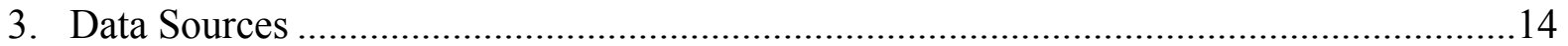

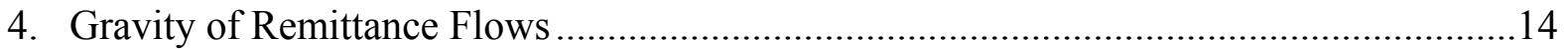

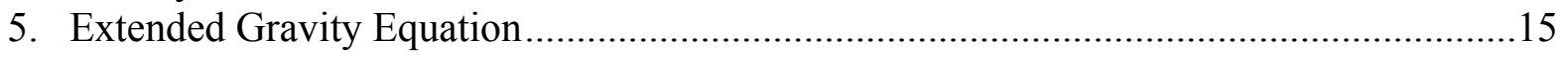

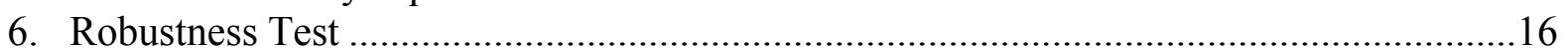




\section{INTRODUCTION}

Workers' remittances have recently attracted much attention in research and policy circles, owing to their scale and properties. As a global aggregate, workers' remittances are the largest source of foreign financing after FDI, exceeding both official development assistance and portfolio investment by a wide margin. In 2004, remittances to India, China, and Mexico alone amounted to $\$ 60$ billion, compared to $\$ 80$ billion in official development assistance worldwide. For a number of developing countries, remittances beat merchandise exports as the prime foreign exchange earner and some 20 countries reported remittances equivalent to 10 percent of GDP or more. Remittances are much more stable over time than private capital flows and exports, making them a very attractive source of foreign financing. In addition, they are unrequited transfers that, unlike other capital flows, do not create obligations in the future. While some of the recent surge in remittances may be due to better recording, the trend is underpinned by mounting demographic pressures in the developed world.

Given remittances' scale, trend, and impact on the receiving country, their determinants need to be better understood. Policymakers and forecasters are particularly interested in what policies may encourage remittances and how they move with other macroeconomic variables, including world oil prices, GDP in the host country, or the exchange rate in the home country. The latter will help illuminate the role of remittances in buffering economic shocks, such as terms of trade shocks, large swings in capital flows, or natural disasters. An analysis of the determinants of remittances should focus broadly on three sets of variables, namely variables associated with the migrant's home country, variables related to the migrant's host country, and variables that describe the relationship between the migrant's home and host countries together with factors affecting both countries simultaneously.

So far, the study of the macroeconomic determinants of remittances has been severely constrained by the lack of data on bilateral flows. The main data source on remittances, the balance of payments statistics published by the IMF, reports aggregate inward and outward remittances for a given country, but gives no breakdown by country of origin or destination. To capture variables related to both workers' host and home countries some papers have focused on a small set of countries (mostly a single one), whose diaspora is concentrated in a known country, or small group of countries. ${ }^{1}$ The only study that analyzes inward remittances for a large panel of countries proxies economic conditions in the host countries by global variables such as oil prices, world output, and LIBOR (see IMF, 2005). Both approaches have obvious shortcomings: the findings of the first lack generality, while the second relies on proxies for potentially important determinants of remittances. Indeed, LIBOR and world output may be poor proxies for investment opportunities and economic

\footnotetext{
${ }^{1}$ See Elbadawi and Rocha (1992), Swami (1981), Straubhaar (1986), El Sakka and McNabb (1999), Bouhga-Hagbe (2004), and Gupta (2005).
} 
activity in the host countries, given that South-South remittance flows account for 30-45 percent of total remittances received by developing countries (World Bank, 2006).

This paper, for the first time, estimates a gravity model for remittances using a novel dataset with bilateral remittance flows. The remittance data was obtained from 11 countries in Asia and Europe that break down their remittance receipts by country of origin and spans the period 1980-2004. The dataset consists of about 200 country pairings and nearly 1,650 observations. Remittance data was provided by the central banks and compiled using international transactions reporting systems and surveys.

The paper contributes in several ways to the existing literature. First, it applies a gravity model, typically used to explain trade and, recently, FDI flows, to workers' remittances. Second, the paper no longer relies on proxies such as oil prices and LIBOR to capture the economic conditions in the migrant workers' host countries. The framework also allows us to test a whole new set of variables as potential determinants of remittances, namely variables that describe the relationship between workers' host and home country, such as distance, common border, shared history, or bilateral trade. Third, we include hitherto untested variables, such as the dependency ratio and an indicator of natural disasters, shedding new light on the motives to remit (altruism versus portfolio considerations). Finally, we derive implications about the cyclical properties of remittances and their role in limiting vulnerability to shocks.

We find that the gravity framework is very powerful in explaining remittance flows. In fact, a few gravity variables such as partner countries' GDP, distance, and common language can explain more than 50 percent of the variation in remittance flows across time and countries. This is broadly in line with results from more common gravity models for trade, which report $\mathrm{R}^{2}$ in the range of 50 percent to 60 percent (e.g., Feenstra and others, 2001). Beyond the common gravity variables we find a number of other variables to be significant in explaining remittance flows. Most notably, trade linkages and colonial ties between home and host countries emerge as strong indicators of the propensity to remit.

The evidence on the motives to remit is mixed, but altruism may be less of factor than commonly believed. The paper does find a positive association between remittance receipts and the dependency ratio in the home country, suggesting that helping those at home is an important motive. Higher inflation in the home country is also found to encourage remittances to compensate for the loss of purchasing power at home. However, remittances do not appear to increase in the wake of natural disasters and appear positively aligned with the business cycle in the home country, evidence favoring the investment motive. Remittances are also sensitive to the investment and political climate in the home and host countries, again suggesting that investment considerations play an important role. 
The results suggest that remittances can play some role, but perhaps not a major one, in limiting vulnerability to shocks. Being procyclical, remittances tend to falter when exports weaken and GDP growth slows. They also decline when the home investment and political climate worsens and do not seem to respond to adverse shocks at home. Moreover, depreciation of the home country's currency tends to reduce remittances, suggesting they may provide only limited insurance against balance of payment crises.

Earlier evidence on the importance of transaction costs for explaining remittances is confirmed and extended to conditions in the host countries. Both underdeveloped financial sectors and current account restrictions in the home country may discourage remittances through official channels, as do dual exchange rates in the workers' host country.

The paper concludes that while remittances should be encouraged they should not be seen as a panacea. Remittances can yield important economic benefits to recipient countries, providing financing and supporting consumption and investment. But they may be of only limited value in absorbing shocks and reducing vulnerability to crisis. To encourage remittances and maximize their economic impact, policies should be directed at reducing transaction costs, promoting financial sector development, and improving the business climate.

The paper is organized as follows. Section II discusses the data and presents some summary statistics, Section III presents the empirical results, and Section IV concludes.

\section{DATA}

To date, lack of data on bilateral remittance flows has been an important shortcoming in the analysis of the determinants of workers' remittances. The IMF balance of payments statistics - the main data source on remittances - reports aggregate inward and outward flows for a given country, but gives no breakdown by country of origin or destination. As a result, it has been impossible to incorporate the economic conditions of the individual host countries as potential determinants of remittances in a cross-country analysis.

This paper creates the first dataset of bilateral remittance flows for a limited set of developing countries for which such data exist. A data query to the central banks of 33 developing countries with significant remittance receipts in Asia, Europe, and the Middle East produced bilateral remittance data for 11 recipient countries: Bangladesh, Croatia, Indonesia, Kazakhstan, FYR Macedonia, Moldova, Philippines, Serbia and Montenegro, Slovenia, Tajikistan, and Thailand. ${ }^{2}$ These countries produce estimates of inward remittances

\footnotetext{
${ }^{2}$ Latin America was excluded from the analysis, as most of its remittances originate in the United States, and this corridor has been widely studied by the Inter-American Development Bank (IADB), among others.
} 
by country of origin using a variety of sources, including the International Transaction Recording System (ITRS), migrant surveys and statistics, as well as statements and surveys of banks and money operators. The number of source countries as well as the time period covered in the dataset vary across recipient countries. On average, each recipient country has recorded flows from about 16 source countries and over a period of nine years (details can be found in Table 1). This amounts to almost 1,650 bilateral remittance observations, albeit the number used in some of the econometric analysis is slightly lower owing to data limitations on some of the control variables. ${ }^{3}$

Bilateral flows captured in our dataset account for nearly 90 percent of all remittances recorded in the balance of payments of these countries. The coverage varies across countries, from 75 percent of all BOP remittances accounted for in the case of Bangladesh to 99 percent for Indonesia. In terms of the global market, the countries in our sample received about 15 percent of the total amount of remittances to developing countries in the period 2002-2004.

The data's main summary statistics are presented in Table 2 . The average recipient country in the sample receives about $\$ 93$ million dollars per host country and per year. Nevertheless, the dispersion of bilateral flows is large, with countries receiving as little as of $\$ 100,000$ per host country per year and as much as $\$ 6.4$ billion (in the case of remittances sent from the United States to the Philippines in 1998). South and East Asia (Bangladesh, Indonesia, Philippines, and Thailand) receive the greatest bilateral remittance flows in absolute terms ( $\$ 150$ million per host country per year on average), while Central Asia (Kazakhstan, Tajikistan) reports the largest bilateral receipts in terms of GDP (9.5 percent of GDP on average).

The empirical analysis is based on an unbalanced panel over the period 1980-2004. The data sources of the gravity variables have been widely used in more common models for trade: GDP data are drawn from the international financial statistics dataset of the IMF and the time invariant factors - distance, common language, and shared border-come from the CIA's World Factbook. Other macroeconomic variables come primarily from IMF databases (International Financial Statistics, Direction of Trade Statistics, and Annual Report on Exchange Arrangements and Exchange Restrictions). Additional data sources are the World Development Indicators of the World Bank (dependency ratio), the International Migration Dataset of the United Nations (stock of migrants), the International Country Risk Guide (political risk), DataStream (stock market returns), CEPII (colonial relationship), and the International Disaster Database (earthquakes, floods, and wind storms). The list of variables and data sources used in the empirical analysis are shown in Table 3.

\footnotetext{
${ }^{3}$ The simplest gravity equation uses about 1640 of these country pairs and our preferred specification uses 1,108 observations. Additional variables are tested in a more restrictive sample of 891 observations.
} 


\section{EMPIRICAL RESULTS}

The empirical framework in this paper is based on a gravity model, well known for its empirical success in explaining international trade flows. In its simplest form, the gravity equation for trade states that trade flows between two countries are proportional to the two countries' economic sizes (GDPs) and inversely proportional to the distance between them. The model often includes variables to account for income level (GDP per capita) and physical and cultural proximity (shared border, language relationship, and colonial history). Other factors either enhancing or impeding trade, such as price levels and tariffs, have also been included in extended specifications. The model has also been used to test the trade impact of currency unions, trade agreements, and organizations such as WTO and NAFTA. More recently, gravity models have also been applied to explain FDI and migration flows. ${ }^{4}$

We model remittance flows from country $j$ to country $i$ at time period $t$ using the following specification:

$$
\ln R_{i j t}=\beta_{0}+\beta_{1} \ln G D P_{i t}+\beta_{2} \ln G D P_{j t}+\beta_{3} \ln D_{i j}+\beta_{4}^{\prime} X_{i j t}+\eta_{t}+\varepsilon_{i j t}
$$

where $R_{i j t}$ is the total amount of remittances received by country $i$ from country $j$ at time period $t$ expressed in dollars; $\mathrm{GDP}_{i t}$ is the nominal gross domestic product of country $i$ in period $t, D_{i j}$ is the physical distance between the two countries; $X_{i j t}$ is a vector of potential factors influencing remittance flows; and $\eta_{t}$ denotes time effects.

We first estimate the simplest form of (1), where vector $X$ includes GDP per capita of both countries (to account for income levels), a dummy variable equal to one if the two countries share a border, and a dummy variable equal to one if the two countries have a common language (to account for cultural proximity). This equation is estimated using 1639 bilateral remittance observations for 11 recipient countries and an average of 16 sending countries for each recipient country, spanning the period 1980-2004. Table 4 presents the estimation results using various econometric techniques: (i) pooled ordinary least squares; (ii) fixed effects for region of origin and region of destination; (iii) fixed effects for receiving country and sending country; and (iv) random effects specific to country pairs. All regressions include time effects to account for common shocks.

Consistent with trade studies, we find that the gravity framework is very powerful in explaining remittance flows. Indeed, the standard gravity factors alone can explain more than half of the variation in bilateral remittance flows. As expected, larger countries receive (and

\footnotetext{
${ }^{4}$ The theoretical foundations of the gravity equation can be found in Anderson (1979), Deardorff (1984) among others. See Demekas and others (2005) and Gupta and Mody (2006) for recent applications of gravity model to FDI and migration flows, respectively.
} 
send) larger volumes of remittances in dollar terms. ${ }^{5}$ The greater the distance between the two countries, the smaller the flow of remittances. Poorer countries (in terms of per capita income) attract more remittance flows and a larger volume of remittances is sent from richer host countries. Sharing a language is positively associated with remittance flows, but sharing a border has either a negative or no statistically significant impact. This may suggest that sharing a border facilitates remittances through nonofficial transfer channels, not captured in our remittance data. It is also possible that migrants choose to hedge themselves (and their families) by moving to countries where cycles are different from those at home-typically countries that do not share a border with the home country.

We next estimate an extended form of (1) where vector $X$ contains a richer set of determinants of remittances. This is done in an attempt to explain some of the variation of remittance flows with relevant macroeconomic and policy variables in the recipient and host countries, rather than using country specific fixed or random effects. At the same time, this minimizes the bias that imposing fixed effects introduces into a dynamic panel. For the first time, this framework allows to incorporate variables that describe the relationship between the two countries, such as colonial linkages and bilateral trade flows, and to use the actual economic conditions in the host country rather than proxies, such as trading partners' GDP, LIBOR, and oil prices.

The additional set of conditioning variables comprises: real per capita growth in the two countries; an indicator variable for natural disasters in the home country; the total stock of migrants in the host country; ${ }^{6}$ a dummy variable for common colonial history of home and host country; financial development in the host and home country proxied by private sector credit as a share of GDP; bilateral export flows from country $i$ (home) to country $j$ (host); imports of country $i$ from country $j$; the inflation differential between the two countries, depreciation of the home country currency against the host country currency; the difference in stock market returns; the dependency ratio (fraction of child and elderly population) of the recipient country; a dummy for multiple exchange rates in the host and home country; and a dummy indicating whether the recipient country has imposed restrictions on current account transactions. Table 5 presents pooled ordinary least square estimates of this extended gravity model using 1,108 bilateral remittance observations.

Beyond the standard gravity factors, we find a number of variables to be significant in explaining remittance flows. The aggregate stock of migrants in the host country is positively associated with remittance flows confirming that the two phenomena-migration and

\footnotetext{
${ }^{5}$ Our results are robust to using population, rather than nominal GDP, as the scale variable in the gravity equation.

${ }^{6}$ A disaggregation of the stock of migrant by country of origin was not available. The lack of these data also preclude an analysis of the determinants of remittances per migrant.
} 
remittances - are closely linked. Trade relations are an important determinant of remittance flows, as well. More remittances are sent from trade partners than from nonpartners, and in particular from destinations of the home country's exports. The positive correlation of remittance receipts and exports over time undermines the usefulness of remittances as a hedge against shocks. While generally less volatile than other sources of foreign exchange, remittances are likely to weaken when exports weaken and hence exacerbate balance of payment pressures. In addition to trade linkages, colonial relationships seem to be relevant; bilateral flows between countries with colonial ties are almost one and a half times larger than those without a colonial history. ${ }^{7}$ This might not be surprising given the fact that many developed countries tend to have preferential visa arrangements with their former colonies.

The evidence on the motives of remittances is mixed. According to the altruism approach, remittances are seen as compensatory transfers between family members and they are motivated by welfare and insurance considerations. Under the portfolio approach, remittances are profit driven and respond to investment opportunities in the home country.

The positive coefficient of the dependency ratio lends further support to the altruism hypothesis. More specifically, a one percentage point increase in the share of the dependent population in the home country boosts remittance flows by about 8.5 percent. Also in favor of the altruism hypothesis - by undermining the alternative hypothesis - is the fact that favorable stock market returns do not appear to be significant in attracting more remittance flows. This finding is in line with the literature, which consistently fails to establish a positive link between rates of return and remittances (see, for example, Swami (1981), Elbadawi and Rocha (1992), Straubhaar (1981), IMF (2005)).

On the other hand, we also find evidence that remittances are profit driven and governed by portfolio considerations; or evidence simply at odds with the altruism hypothesis. For example, we do not find evidence that remittances increase following a natural disaster in the home country. And, this is so regardless of the measure of natural disaster employedearthquakes, floods or wind storms. This result runs counter to the altruism hypothesis which predicts that remittances compensate for the reduced income of family members in the wake of natural disasters. Lending support to the portfolio approach is the positive coefficient associated with the home country's growth rate of GDP per capita. A one percentage point increase in this growth rate is associated with 2.8 percent higher remittances. This suggests that migrants tend to send more remittances when the economic conditions back home improve, possibly for investment purposes. ${ }^{8} \mathrm{We}$ also find that greater economic activity in

\footnotetext{
${ }^{7}$ The coefficient of the dummy indicator for colonial relationship is 0.98 . Thus, the impact on remittance flows is computed as $\left(\mathrm{e}^{0.89}-1\right)=1.43$.

${ }^{8}$ Giuliano and Ruiz-Arranz (2005) using the Hodrick-Prescott filtering technique conclude that remittance receipts tend to be procyclical in about two thirds of the developing world and Sayan (2006) finds that countercyclicality of remittance is not commonly observed in a study of 12 developing countries.
} 
the host country encourages migrants to keep their savings in the host country rather than sending them back as remittances - further evidence that portfolio considerations are at play. The latter findings are somewhat unconventional, given that altruism is widely believed to be the dominant motive behind remittances (see Lucas and Stark,1985; Rapoport and Docquier, 2005). The findings also call into question the perceived usefulness of remittances in alleviating poverty and buffering against shock (e.g., IMF, 2005; World Bank, 2006).

We find evidence that migrants seek to stabilize remittances in real terms. Higher inflation in the home country is found to encourage more remittance flows to compensate for the loss of purchasing power. ${ }^{9}$ However, depreciation of the home country's currency reduces remittances as less dollars buy the same goods basket as before the depreciation. The desire to maintain remittances' purchasing power, irrespective of price changes, is more easily reconcilable with altruistic behavior than with a quest for profit.

The regression results also confirm that financial development, particularly in the home country, encourages remittance flows. Similarly, fewer restrictions on current account transactions in the recipient economy considerably enhance remittance flows; as does the removal of existing dual exchange rates in the host country. In fact, countries that restrict current account transactions receive 40 percent less remittances on average than countries with fully liberalized current accounts. And up to 80 percent fewer remittances are sent from host countries with dual exchange rates. These results have also important implications from a policy point of view and indicate that the current policy of facilitating flows by promoting lower transaction costs, less restrictions on payments, and greater competition among money market operations are well placed. In addition, fostering financial sector development in the receiving country is key to attracting more remittances through formal channels, and possibly enhancing their development impact.

Despite the importance of remittances in Asia-Asia and the Pacific is the main destination region for remittances, accounting for 45 percent of the global total-South and East Asia receive fewer remittances than predicted by the model. This is also borne out by the fact that South and East Asia are the leading recipients of remittances in absolute terms, but lagging when it comes to remittances as a share of GDP, compared to some countries in Central Asia and Southeastern Europe. We also find evidence of a positive correlation between remittances and the host country being a net oil exporter or an advanced economy. However, this correlation turns statistically insignificant once other variables capturing economic activity, such as growth rate, are controlled for.

\footnotetext{
${ }^{9}$ This result is in contrast with Elbadawi and Rocha (1992) who claim that high domestic inflation might be a proxy for macroeconomic and/or political instability and, hence, discourage remittance inflows.
} 
A country's political stability — broadly defined to reflect government stability, socioeconomic conditions, investment climate, internal and external conflict, corruption, involvement of the military in politics, religious tensions, law and order, ethnic tensions, democratic accountability, and bureaucracy quality - also constitutes an important determinant of remittance flows. This variable was not incorporated in the previous analysis due to limited availability of data for some of the countries used in the study. But, a separate regression is estimated for a reduced sample (891 bilateral observations) incorporating the ICRG rating of political risk..$^{10}$ Our results (Column 2, Table 5) show that remittances are sensitive to political conditions in the two countries. Less political risk (i.e., a higher rating) in the home country leads to larger volumes of remittances. Similarly, political instability and unfavorable business climate in the host country, by reducing their opportunity costs, encourages more remittances.

The regression results, and in particular the magnitude of the effects, should be interpreted with caution, as the analysis may suffer from endogeneity bias. For instance, there is evidence of causality running from remittances to financial development. Indeed Aggarwal and others (2006) find that remittances foster financial development by increasing the aggregate level of deposits and credit intermediated by local banks. Large remittance flows have also stimulated product innovation in the field of savings and investment instruments. Other sources of reverse causality may arise if remittances affect growth, exports, inflation or the exchange rate. Giuliano and Ruiz-Arranz (2005) provide evidence that remittances have a positive impact on growth in some countries. There is also increasing evidence that migrants have become a new market attracting exports from their home countries as well as anecdotal evidence that large remittance inflows have created inflation in the housing market of certain regions in Latin America. Despite evidence to the contrary (Rajan and Subramanian, 2004), large remittance flows may also lead to real exchange rate appreciation or Dutch disease. Finally, large emigration of working age population may cause both larger remittance receipts and an increase in the country's dependency ratio.

Some robustness checks are performed in an attempt to minimize endogeneity concerns. First, we lag all variables thought to simultaneously be affected by, and affect remittances, namely financial development, growth, trade, the dependency ratio, inflation and the exchange rate. By using lagged values we expect the contemporaneous effect of remittances on these variables to be eliminated, and hence the bias that these interactions might introduce. As Table 6 shows, the main results are robust to this new specification. However, the exchange rate variable loses its significance. Second, to test the robustness of the procyclicality of remittances, i.e., the positive coefficient associated with growth in the home country, we instrument this potentially endogenous variable with its own lagged values. This is approach is borrowed from the generalized method of moments. Again, all coefficient

\footnotetext{
${ }^{10}$ Risk ratings range from a high of 100 (least risk) to a low of 0 (highest risk).
} 
estimates, except for the one associated with the dependency ratio, are robust to this instrumentation technique.

\section{Conclusions And Policy Implications}

More than 50 percent of the variation in bilateral remittance flows can be explained by a few gravity variables such as partner countries' GDP, distance, shared border, and common language. With key macroeconomic variables (inflation, growth, exchange rate, trade) and variables capturing transaction costs (financial sector development, dual exchange rates, current account restrictions) added to the set of explanatory variables, more than 70 percent of the variation in remittances can be explained.

The evidence on the motives to remit is mixed, but altruism seems to be less of a factor than commonly believed. Most strikingly, remittances do not increase in the wake of natural disasters and are sensitive to the investment climate in the home and host country. Also, somewhat at odds with conventional wisdom, remittance receipts are aligned with the business cycle in the home country.

Earlier evidence on the importance of transaction costs for explaining remittance receipts through official channels is confirmed and extended to conditions in the workers' host countries. Both underdeveloped financial sectors and current account restrictions in the home country discourage remittances through official channels, as do dual exchange rates in the workers' host country.

Remittance receipts may be less of a shock absorber than commonly claimed. Being procyclical, they falter when exports weaken and GDP growth slows. They also stay away when the investment climate worsens - even if it is only relative to the sending country - and do not seem to respond to adverse shocks at home. Moreover, depreciation of the home country's currency tends to reduce remittances, suggesting they may provide only limited insurance against balance of payment crisis.

These findings have important implications. Policymakers who want to generate more remittance receipts through official channels are well advised to tackle financial sector deficiencies, ease current account restrictions, and discontinue dual exchange rate practicesand convince main sending countries to do the same. Remittances should be encouraged as they can yield important economic benefits to recipient countries. However, they might not play a major role in limiting vulnerability to shocks and cannot substitute for good policies and structural reforms. 
Table 1. Remittance Flow Data

\begin{tabular}{lccc}
\hline $\begin{array}{l}\text { Recipient } \\
\text { Country }\end{array}$ & $\begin{array}{c}\text { Number } \\
\text { Source } \\
\text { Countries }\end{array}$ & $\begin{array}{c}\text { Time } \\
\text { Period }\end{array}$ & $\begin{array}{c}\text { Data } \\
\text { Coverage 1/ }\end{array}$ \\
\hline Bangladesh & 12 & $1979-2004$ & 75 \\
Croatia & 25 & $1997-2004$ & 96 \\
Indonesia & 12 & $2003-2004$ & 99 \\
Kazakhstan & 19 & $2003-2004$ & 67 \\
Macedonia FYR & 19 & $1997-2004$ & 97 \\
Moldova & 15 & $2003-2004$ & 94 \\
Philippines & 31 & $1981-2004$ & 85 \\
Serbia and Montenegro & 19 & $2000-2004$ & 92 \\
Slovenia & 16 & $1994-2004$ & 95 \\
Tajikistan & 3 & $2002-2004$ & 97 \\
Thailand & 21 & $1993-2004$ & 95 \\
\hline
\end{tabular}

1/ Percent of total remittances from the balance of payments covered in the dataset (average all years).

Table 2. Summary Statistics

\begin{tabular}{|c|c|c|c|c|c|c|}
\hline Variable & Units & Observation & Mean & $\begin{array}{l}\text { Standard } \\
\text { Deviation }\end{array}$ & Minimum & Maximum \\
\hline Remittance flow from $\mathrm{j}$ to $\mathrm{i}$ & US\$ million & 1,108 & 93 & 421 & 0.1 & 6403 \\
\hline Nominal GDP country i & US\$ billion & 1,108 & 54.6 & 46.3 & 2.0 & 182.0 \\
\hline Nominal GDP country j & US\$ billion & 1,108 & 1,134 & 2,247 & 2 & 11,734 \\
\hline GDP per capita country i & US\$ & 1,108 & 3,101 & 3,529 & 162 & 16,161 \\
\hline GDP per capita country j & US\$ & 1,108 & 20,928 & 11,467 & 380 & 69737 \\
\hline Common border & Dummy; $1=y e s$ & 1,108 & 0.1 & 0.3 & 0 & 1 \\
\hline Log distance & Kilometers & 1,108 & 8.1 & 1.1 & 4.7 & 9.7 \\
\hline Common language & Dummy; $1=y e s$ & 1,108 & 0.2 & 0.4 & 0 & 1 \\
\hline Colonial relationship & Dummy; $1=y e s$ & 1,108 & 0.1 & 0.2 & 0 & 1 \\
\hline Stock of migrants in country j & Millions & 1,108 & 4.3 & 8.2 & 0 & 35 \\
\hline Exports from i to $\mathrm{j}$ & US\$ million & 1,108 & 836 & 1,966 & 0 & 15,498 \\
\hline Imports of $\mathrm{i}$ from $\mathrm{j}$ & US\$ million & 1,108 & 931 & 2,205 & 0 & 22,379 \\
\hline Dependency ratio in country $\mathrm{i}$ & Percent of population & 1,108 & 36.0 & 6.0 & 29.2 & 49.5 \\
\hline Per capita growth country i & In percent of GDP & 1,108 & 2.5 & -3.6 & 11.6 & 9.3 \\
\hline Per capita growth country j & In percent of GDP & 1,108 & 2.0 & 4.6 & -29.7 & 44.3 \\
\hline Differential stock market returns & In percent & 1,108 & -5.5 & 39.7 & -392.8 & 181.3 \\
\hline Credit to private sector in country $\mathrm{i}$ & In percent of GDP & 1,108 & 41.9 & 26.5 & 7.3 & 121.1 \\
\hline Credit to private sector in country $\mathrm{j}$ & In percent of GDP & 1,108 & 78.3 & 41.5 & 4.7 & 170.3 \\
\hline Inflation differential & In percent & 1,108 & 2.9 & -8.8 & 83.6 & 48.3 \\
\hline Depreciation differential & In percent & 1,108 & 3.7 & 13.8 & -212.3 & 50.4 \\
\hline Restrictions on current account & Dummy; $1=y e s$ & 1,108 & 0.5 & 0.5 & 0 & 1 \\
\hline Dual exchange rate in country $\mathrm{i}$ & Dummy; $1=y e s$ & 1,108 & 0.0 & 0.2 & 0 & 1 \\
\hline Dual exchange rate in country j & Dummy; $1=y e s$ & 1,108 & 0.0 & 0.1 & 0 & 1 \\
\hline Earthquake & Dummy; $1=y e s$ & 1,108 & 0.1 & 0.3 & 0 & 1 \\
\hline Flood & Dummy; $1=y e s$ & 1,108 & 0.4 & 0.5 & 0 & 1 \\
\hline Wind storm & Dummy; 1=yes & 1,108 & 0.5 & 0.5 & 0 & 1 \\
\hline Political risk country i & $100=\min$. risk $; 0=\max$ risk & 891 & 64 & 13 & 29 & 81 \\
\hline Political risk country j & $100=$ min. risk $0=\max$ risk & 891 & 78 & 11 & 44 & 96 \\
\hline
\end{tabular}


Table 3. Data Sources

\begin{tabular}{ll}
\hline Variable & \\
\hline Remittance flows & IMF, Balance of Payments Statistics; and authors' calculations \\
Nominal GDP & IMF, International Financial Statistics \\
GDP per capita & IMF, International Financial Statistics \\
Distance & Andrew Rose's website; and authors' calculations 1/ \\
Common language & Andrew Rose's website; and authors' calculations 1/ \\
Shared border & Andrew Rose's website; and authors' calculations 1/ \\
Colonial history & CEPII dataset \\
Stock of migrants & United Nations, International Migration Data \\
Bilateral exports & IMF, Direction of Trade Statistics \\
Bilateral imports & IMF, Direction of Trade Statistics \\
Real GDP growth per capita & IMF, International Financial Statistics \\
Natural disaster & EM-DAT: The OFDA/CRED International Disaster database \\
Dependency ratio & World Bank, World Development Indicators \\
Stock market returns & Datastream \\
Credit to the private sector & IMF, International Financial Statistics \\
Inflation & IMF, International Financial Statistics \\
Depreciation & IMF, International Financial Statistics \\
Restrictions current account & IMF, Annual Report on Exchange Arrangements and Exchange Rate Restrictions \\
Dual exchange rate & IMF, Annual Report on Exchange Arrangements and Exchange Rate Restrictions \\
Political Risk & International Country Risk Guide dataset (ICRG) \\
\hline
\end{tabular}

1/ http://faculty.haas.berkeley.edu/arose/.

Table 4. Gravity of Remittance Flows 1/

\begin{tabular}{|c|c|c|c|c|}
\hline \multicolumn{5}{|c|}{ Dependent variable is Log Remittance Flows from country $i$ to country $j$} \\
\hline Log GDP_i & $\begin{array}{l}0.846^{* * *} \\
(0.04)\end{array}$ & $\begin{array}{l}1.243^{* * *} \\
(0.10)\end{array}$ & $\begin{array}{l}3.952 \text { *** } \\
(1.45)\end{array}$ & $\begin{array}{l}0.882 \text { *** } \\
(0.09)\end{array}$ \\
\hline $\log _{\text {GDP }} \mathrm{j}^{\mathrm{j}}$ & $\begin{array}{l}0.45^{* * *} \\
(0.02)\end{array}$ & $\begin{array}{l}0.581^{* * *} \\
(0.03)\end{array}$ & $\begin{array}{l}0.065 \\
(0.42)\end{array}$ & $\begin{array}{l}0.392 \text { *** } \\
(0.07)\end{array}$ \\
\hline Log GDP per capita _ i & $\begin{array}{l}-1.457^{* * *} \\
(0.05)\end{array}$ & $\begin{array}{r}-1.815 \\
(0.09)\end{array}$ & $\begin{array}{l}-3.546^{* * *} \\
(1.34)\end{array}$ & $\begin{array}{l}-1.218^{* * *} \\
(0.11)\end{array}$ \\
\hline Log GDP per capita_j & $\begin{array}{l}0.287^{* * *} \\
(0.06)\end{array}$ & $\begin{array}{l}0.086 \\
(0.08)\end{array}$ & $\begin{array}{l}1.194^{* * *} \\
(0.38)\end{array}$ & $\begin{array}{l}0.539 \text { *** } \\
(0.10)\end{array}$ \\
\hline Log Distance & $\begin{array}{l}-0.53^{* * *} \\
(0.05)\end{array}$ & $\begin{array}{l}-0.508^{* * *} \\
(0.05)\end{array}$ & $\begin{array}{l}-0.245^{* * *} \\
(0.07)\end{array}$ & $\begin{array}{l}-0.544 \text { *** } \\
(0.13)\end{array}$ \\
\hline Shared border & $\begin{array}{l}-0.611^{* * *} \\
(0.18)\end{array}$ & $\begin{array}{l}-0.548 \text { *** } \\
(0.18)\end{array}$ & $\begin{array}{r}-0.055 \\
(0.19)\end{array}$ & $\begin{array}{r}-0.411 \\
(0.40)\end{array}$ \\
\hline Common language & $\begin{array}{l}0.529 * * * \\
(0.09)\end{array}$ & $\begin{array}{l}0.594^{* * *} \\
(0.09)\end{array}$ & $\begin{array}{l}0.596 * * * \\
(0.12)\end{array}$ & $\begin{array}{l}0.472 \text { * } \\
(0.27)\end{array}$ \\
\hline Constant & $\begin{array}{l}7.177^{\text {*** }} \\
(0.86)\end{array}$ & $\begin{array}{c}11.128 \text { *** } \\
(1.08)\end{array}$ & $\begin{array}{l}0.831 \\
(3.86)\end{array}$ & $\begin{array}{l}2.494 \\
(1.66)\end{array}$ \\
\hline Observations & 1,639 & 1,639 & 1,639 & 1,639 \\
\hline R-squared & 0.53 & 0.58 & 0.73 & 0.5 \\
\hline Number of country-pairs & $\ldots$ & $\ldots$ & $\ldots$ & 190 \\
\hline Specific effects & No & $\begin{array}{l}\text { Region (home } \\
\text { and host) } \\
\text { fixed effects }\end{array}$ & $\begin{array}{l}\text { Country (home } \\
\text { and host) } \\
\text { fixed effects }\end{array}$ & $\begin{array}{l}\text { Country-pair } \\
\text { random effects }\end{array}$ \\
\hline
\end{tabular}

1/ All regressions include time fixed effects. Standard errors in parentheses; * significant at 10 percent; ${ }^{* *}$ significant at 5 percent; ${ }^{* * *}$ significant at 1 percent. 
Table 5. Extended Gravity Equation 1/

\begin{tabular}{|c|c|c|}
\hline \multicolumn{3}{|c|}{ Dependent Variable is Log Remittance Flows From Country $j$ to Country $i$} \\
\hline Log GDP_i & $\begin{array}{l}1.281^{* * *} \\
(0.16)\end{array}$ & $\begin{array}{l}0.971 \text { *** } \\
(0.24)\end{array}$ \\
\hline $\log _{\text {GDP }} \mathrm{j}$ & $\begin{array}{l}0.168^{* * *} \\
(0.06)\end{array}$ & $\begin{array}{l}0.184^{* * *} \\
(0.06)\end{array}$ \\
\hline Log GDP per capita_i & $\begin{array}{l}-2.835 \\
(0.18)\end{array}$ & $\begin{array}{l}-4.172^{* * *} \\
(0.38)\end{array}$ \\
\hline Log GDP per capita _ j & $\begin{array}{l}0.339^{* * *} \\
(0.08)\end{array}$ & $\begin{array}{l}0.327^{* * *} \\
(0.10)\end{array}$ \\
\hline Log distance & $\begin{array}{l}-0.346^{* * *} \\
(0.07)\end{array}$ & $\begin{array}{l}-0.195 * * \\
(0.08)\end{array}$ \\
\hline Shared border & $\begin{array}{l}-0.492^{* * *} \\
(0.18)\end{array}$ & $\begin{array}{l}-0.611 \text { *** } \\
(0.22)\end{array}$ \\
\hline Common language & $\begin{array}{l}0.264 \\
(0.12)\end{array}$ & $\begin{array}{l}0.285 * * \\
(0.12)\end{array}$ \\
\hline Colonial relationship & $\begin{array}{l}0.981^{* * *} \\
(0.19)\end{array}$ & $\begin{array}{l}0.961 \\
(0.21)\end{array}$ \\
\hline Log stock migrants $\_$ & $\begin{array}{l}0.362 \text { *** } \\
(0.05)\end{array}$ & $\begin{array}{l}0.252 \text { *** } \\
(0.05)\end{array}$ \\
\hline Log exports of $\mathrm{i}$ to $\mathrm{j}$ & $\begin{array}{l}0.167^{* * *} \\
(0.04)\end{array}$ & $\begin{array}{l}0.215^{* * *} \\
(0.04)\end{array}$ \\
\hline Log imports of $i$ from $j$ & $\begin{array}{r}-0.042 \\
(0.04)\end{array}$ & $\begin{array}{r}-0.012 \\
(0.04)\end{array}$ \\
\hline Dependency ratio _ i & $\begin{array}{l}0.079^{* * *} \\
(0.03)\end{array}$ & $\begin{array}{r}-0.041 \\
(0.05)\end{array}$ \\
\hline Earthquake_i & $\begin{array}{l}0.075 \\
(0.14)\end{array}$ & $\begin{array}{l}0.107 \\
(0.14)\end{array}$ \\
\hline Per capita GDP growth_i & $\begin{array}{l}0.028 * \\
(0.02)\end{array}$ & $\begin{array}{l}0.002 \\
(0.02)\end{array}$ \\
\hline Per capita GDP growth_j & $\begin{array}{l}-0.017 \text { * } \\
(0.01)\end{array}$ & $\begin{array}{r}-0.009 \\
(0.01)\end{array}$ \\
\hline stock_ij & $\begin{array}{l}0.001 \\
(0.00)\end{array}$ & $\begin{array}{r}0 \\
(0.00)\end{array}$ \\
\hline Credit to GDP_i & $\begin{array}{l}0.019 \text { *** } \\
(0.00)\end{array}$ & $\begin{array}{l}0.028 \\
(0.01)\end{array}$ \\
\hline Credit to GDP ${ }_{-} \mathrm{j}$ & $\begin{array}{l}0.001 \\
(0.00)\end{array}$ & $\begin{array}{l}0.001 \\
(0.00)\end{array}$ \\
\hline Inflation diferential $\mathrm{i}$ to $\mathrm{j}$ & $\begin{array}{l}0.049^{* * *} \\
(0.01)\end{array}$ & $\begin{array}{l}0.038^{* * *} \\
(0.01)\end{array}$ \\
\hline Depreciation $i$ to $j$ & $\begin{array}{l}-0.007 \text { * } \\
(0.00)\end{array}$ & $\begin{array}{l}-0.01 \\
(0.00)\end{array}$ \\
\hline Restrictions CA_i & $\begin{array}{l}-0.503^{* * *} \\
(0.15)\end{array}$ & $\begin{array}{l}0.331 \\
(0.30)\end{array}$ \\
\hline Dual exchange rate _ $\mathrm{i}$ & $\begin{array}{r}-0.125 \\
(0.28)\end{array}$ & $\begin{array}{r}-0.414 \\
(0.33)\end{array}$ \\
\hline Dual exchange rate $j$ & $\begin{array}{l}-1.588 \text { ** } \\
(0.64)\end{array}$ & $\begin{array}{l}-2.941 \\
(0.70)\end{array}$ \\
\hline Political risk_i & & $\begin{array}{l}0.069 \text { *** } \\
(0.02)\end{array}$ \\
\hline Political risk j & & $\begin{array}{l}-0.023 \text { *** } \\
(0.01)\end{array}$ \\
\hline Asia_i & $\begin{array}{l}-4.4644^{* * *} \\
(0.51)\end{array}$ & $\begin{array}{l}-6.417 \text { *** } \\
(0.81)\end{array}$ \\
\hline Developed country j & $\begin{array}{l}0.242 \\
(0.18)\end{array}$ & $\begin{array}{l}0.023 \\
(0.20)\end{array}$ \\
\hline Constant & $\begin{array}{l}7.763^{* * *} \\
(2.35)\end{array}$ & $\begin{array}{c}23.619 \\
(3.46)\end{array}$ \\
\hline Observations & 1108 & 891 \\
\hline R-squared & 0.71 & 0.72 \\
\hline
\end{tabular}

1/ The regression includes time fixed effects. Standard errors in parentheses; * significant at 10 percent; ** significant at 5 percent; ${ }^{* * *}$ significant at 1 percent. 
Table 6. Robustness Test $1 /$

\begin{tabular}{|c|c|}
\hline \multicolumn{2}{|c|}{ Dependent Variable is Log Remittance Flows From Country $j$ to Country $i$} \\
\hline Log GDP_i & $\begin{array}{l}1.623^{* * *} \\
(0.18)\end{array}$ \\
\hline $\log _{\text {GDP _ j }}$ & $\begin{array}{l}0.119 * * \\
(0.06)\end{array}$ \\
\hline Log GDP per capita _ i & $\begin{array}{l}-3.137 * * * \\
(0.19)\end{array}$ \\
\hline Log GDP per capita _ j & $\begin{array}{l}0.311 * * * \\
(0.08)\end{array}$ \\
\hline Log distance & $\begin{array}{l}-0.257 * * * \\
(0.07)\end{array}$ \\
\hline Shared border & $\begin{array}{l}-0.47^{* *} \\
(0.19)\end{array}$ \\
\hline Common language & $\begin{array}{l}0.249 * * \\
(0.12)\end{array}$ \\
\hline Colonial relationship & $\begin{array}{l}0.893 * * * \\
(0.19)\end{array}$ \\
\hline Log stock migrants ذـ ـ & $\begin{array}{l}0.361 * * * \\
(0.05)\end{array}$ \\
\hline Lag log exports of $i$ to $j$ & $\begin{array}{l}0.171 * * * \\
(0.04)\end{array}$ \\
\hline Lag log imports of $i$ from $\mathrm{j}$ & $\begin{array}{r}0.02 \\
(0.04)\end{array}$ \\
\hline Dependency ratio _ i & $\begin{array}{l}0.078^{* * *} \\
(0.03)\end{array}$ \\
\hline Earthquake_i & $\begin{array}{r}0.06 \\
(0.14)\end{array}$ \\
\hline Lag per capita GDP growth_i & $\begin{array}{l}0.03 \text { * } \\
(0.02)\end{array}$ \\
\hline Lag per capita GDP growth & $\begin{array}{r}-0.014 \\
(0.01)\end{array}$ \\
\hline stock_ij & $\begin{array}{r}0 \\
(0.00)\end{array}$ \\
\hline Lag credit to GDP _ ${ }^{\mathrm{i}}$ & $\begin{array}{l}0.018^{* * *} \\
(0.00)\end{array}$ \\
\hline Lag credit to GDP_j & $\begin{array}{l}0.001 \\
(0.00)\end{array}$ \\
\hline Lag inflation diferential $\mathrm{i}$ to $\mathrm{j}$ & $\begin{array}{l}0.036 * * * \\
(0.01)\end{array}$ \\
\hline Lag depreciation $i$ to $j$ & $\begin{array}{r}-0.001 \\
(0.00)\end{array}$ \\
\hline Restrictions CA_i & $\begin{array}{l}-0.4377^{* * *} \\
(0.17)\end{array}$ \\
\hline Dual exchange rate _i & $\begin{array}{r}-0.026 \\
(0.30)\end{array}$ \\
\hline Dual exchange rate $ـ$ & $\begin{array}{l}-2.121 \text { *** } \\
(0.58)\end{array}$ \\
\hline Asia_i & $\begin{array}{l}-5.78^{* * *} \\
(0.56)\end{array}$ \\
\hline Developed country_j & $\begin{array}{l}0.161 \\
(0.19)\end{array}$ \\
\hline Constant & $\begin{array}{l}11.087 * * * \\
(2.37)\end{array}$ \\
\hline Observations & 1025 \\
\hline R-squared & 0.72 \\
\hline
\end{tabular}

$1 /$ The regression includes time fixed effects. Standard errors in parentheses; * significant at 10 percent; ** significant at 5 percent; ${ }^{* \star *}$ significant at 1 percent. 


\section{References}

Aggarwal R., A. Demirgüç-Kunt, M.S. Martinez Peria, 2006, “Do Workers’ Remittances Promote Financial Development?” Policy Research Working Paper No. 3957 (Washington: World Bank).

Anderson, J., 1979, “A Theoretical Foundation for the Gravity Equation,” American Economic Review, Vol. 69, No. 1, pp. 106-16.

Bouhga-Hagbe, Jacques, 2004, “A Theory of Workers' Remittances With an Application to Morocco,” IMF Working Paper 04/194 (Washington: International Monetary Fund).

Central Intelligence Agency, 2005, The World Factbook (Washington).

Deardorff, A., 1984, “Testing Trade Theories and Predicting Trade Flows," in Handbook of International Economics, Vol. 1 (Amsterdam: Elsevier Science Publishers).

Demekas, Dimitri, B. Horváth, El. Ribakova, and Y. Wu, 2005, "Foreign Direct Investment in Southeastern Europe: How (and How Much) Can Policies Help?” IMF Working Paper 05/110 (Washington: International Monetary Fund).

Elbadawi, Ibrahim A., and Robert de Rezende Rocha, 1992, "Determinants of Expatriate Workers' Remittances in North Africa and Europe," Policy Research Working Paper No. 1038 (Washington: World Bank).

El Sakka, M.I.T., and Robert McNabb, 1999, “The Macroeconomic Determinants of Emigrant Remittances,” World Development, Vol. 27, No. 8, pp. 1493-1502.

Feenstra R., J. Markusen, and A. Rose, 2001, "Using the Gravity Equation to Differentiate Among Different Theories of Trade," Canadian Journal of Economics, Vol. 34, No. 2.

Giuliano, Paola, and Marta Ruiz-Arranz, 2005, "Remittances, Financial Development, and Growth," IMF Working Paper 05/234 (Washington: International Monetary Fund).

Gupta, Poonam, 2005, "Macroeconomic Determinants of Remittances: Evidence from India,” IMF Working Paper 05/224 (Washington: International Monetary Fund). , and Ashok Mody, 2007, "Will Factor Flows and Trade be Complements or Substitutes as Europe Enlarges?," IMF Working Paper (forthcoming). 
International Monetary Fund, 2005, World Economic Outlook, April 2005, World Economic and Financial Surveys (Washington).

Lucas, Robert, and Oded Stark, 1985, "Motivations to Remit: Evidence from Botswana," Journal of Political Economy, Vol. 93, pp. 901-18.

Rapoport, Hillel, and Frédéric Docquier, 2005, “The Economics of Migrants' Remittances," IZA Discussion Paper 1531 (Bonn: Institute for the Study of Labor).

Rajan, R., and A. Subramanian, 2005, “What Undermines Aid's Impact on Growth?” IMF Working Paper 05/126 (Washington: International Monetary Fund).

Sayan, Serdar, 2006, “Business Cycles ad Workers' Remittances: How Do Migrant Workers Respond to Cyclical Movements of GDP at Home?" IMF Working Paper 06/52 (Washington: International Monetary Fund).

Straubhaar, Thomas, 1986, "International Migrant Workers' Remittances: The Case of Turkey," Weltwirtschaftliches Archiv, Vol. 122, pp. 728-40.

Swami, Gurushri, 1981, "International Migrant Workers' Remittances: Issues and Prospects,” World Bank Staff Working Paper No. 481 (Washington: World Bank).

World Bank, 2006, Global Economic Prospects: Economic Implications of Remittances and Migration (Washington). 